\title{
PEMBUATAN CRACKERS JAGUNG DAN PENDUGAAN UMUR SIMPANNYA DENGAN PENDEKATAN KADAR AIR KRITIS
}

\author{
[Production of Corn Cracker and Prediction of Its Shelf Life Using a Critical Moisture Approach] \\ Sugiyono ${ }^{1)^{*}}$, Esther Mariana ${ }^{1)}$ dan Aton Yulianto ${ }^{2)}$ \\ 1) Departemen IImu dan Teknologi Pangan, Fakultas Teknologi Pertanian, Institut Pertanian Bogor, Bogor \\ 2) Badan Pengkajian dan Penerapan Teknologi (BPPT), Jakarta
}

Diterima 16 April 2010 / Disetujui 19 April 2013

\begin{abstract}
The objectives of this research were to produce crackers based on corn flour and to predict its shelf life using a critical moisture approach. The best crackers were produced from a mixture of $60 \%$ corn flour and $40 \%$ glutinous rice flour. The products had a puffing ratio of $11 \%$, crispiness of $250.8 \mathrm{gf}$ and hardness of $384.7 \mathrm{gf}$. The corn crackers had better crispiness and hardness than those of commercial rice crackers. The moisture sorption isotherm curve of corn crackers could be described using a Hasley model. Using the critical moisture approach, corn crackers packaged in a metallized plastic and stored at $30^{\circ} \mathrm{C}$ and $75 \%$ relative humidity had a shelf life of 366 days. If the products were stored at $85 \%$ relative humidity, the product shelf life would be 150 days.
\end{abstract}

Keywords: crackers, corn flour, moisture sorption isotherm, shelf life

\begin{abstract}
ABSTRAK
Penelitian ini bertujuan untuk membuat produk crackers dari bahan dasar tepung jagung dan menduga umur simpannya dengan menggunakan pendekatan kadar air kritis. Hasil penelitian menunjukkan bahwa produk crackers dapat dibuat dari campuran tepung jagung dan tepung ketan. Produk terbaik dihasilkan dari campuran tepung jagung $60 \%$ dan tepung ketan $40 \%$. Produk crackers jagung mempunyai rasio pengembangan $11 \%$, nilai kerenyahan 250.8 gf, serta nilai kekerasan 384.7 gf. Produk crackers jagung yang dihasilkan mempunyai kerenyahan dan kekerasan yang lebih baik dibandingkan dengan rice crackers komersial. Kurva isotermis sorpsi air dari crackers jagung dapat digambarkan dengan menggunakan model Hasley. Dengan menggunakan pendekatan kadar air kritis, produk crackers jagung yang dikemas dengan metallized plastic dan disimpan pada suhu $30^{\circ} \mathrm{C}$ dan kelembaban udara $75 \%$ mempunyai umur simpan 366 hari. Jika produk disimpan pada kelembaban udara $85 \%$, umur simpannya menjadi 150 hari.
\end{abstract}

Kata kunci: crackers, isotermis sorpsi air, tepung jagung, umur simpan

\section{PENDAHULUAN}

Jagung merupakan salah satu komoditas pertanian yang penting. Produksi jagung nasional pada tahun 2011 sebanyak 17.6 juta ton (BPS, 2011). Jagung dimanfaatkan sebagai bahan pangan atau pakan. Sebagian besar (85.84\%) jagung digunakan sebagai pakan dan sebagian kecil (6.44\%) jagung digunakan sebagai pangan (Departemen Perindustrian, 2007). Hal ini menunjukkan bahwa pemanfaatan jagung sebagai bahan pangan masih perlu ditingkatkan mengingat jagung sangat potensial sebagai sumber karbohidrat dan protein menggantikan beras.

Pemanfaatan jagung sebagai bahan baku industri pangan selama ini terutama dalam bentuk pati dan grits. Pati jagung banyak dimanfaatkan sebagai bahan baku dalam pembuatan berbagai produk pangan diantaranya saus sambal/tomat, biskuit, sirup glukosa/fruktosa, dan lain-lain. Grits jagung banyak digunakan sebagai bahan baku produk makanan ringan

*Penulis Korespondensi:

E-mail: sugiyono@ipb.ac.id; Telp.: +62-251-8628253 (snack food). Sugiyono et al. (2004) dan Supriadi et al. (2004) mengolah grits menjadi "beras jagung instan". Agustina (2008) membuat bubur jagung instan dari grits jagung.

Penggunaan jagung dalam bentuk tepung relatif belum berkembang secara signifikan. Oleh karena itu, pemanfaatan tepung jagung sebagai bahan pangan merupakan tantangan yang menarik untuk dieksplorasi sehingga dapat meningkatkan nilai tambah jagung. Beberapa penelitian telah dilakukan dalam rangka memanfaatkan tepung jagung sebagai bahan baku berbagai produk pangan. Fitriani (2004) membuat mi jagung dari tepung jagung. Cynthia et al. (2009) memanfaatkan tepung jagung sebagai bahan baku dalam pembuatan biskuit. Sugiyono et al. (2010) memanfaatkan tepung jagung sebagai tepung penyalut (batter).

Penelitian ini bertujuan membuat produk crackers berbahan dasar tepung jagung dan menduga umur simpannya dengan menggunakan pendekatan kadar air kritis. Pembuatan crackers dengan memanfaatkan tepung jagung merupakan pengembangan produk baru (corn crackers) yang berbasis komoditas lokal. Crackers yang dimaksud adalah sejenis rice crackers atau opak. Rice crackers biasanya dibuat dari beras atau ketan 
(Putra, 2005). Dalam pembuatan rice crackers atau opak diperlukan tepung yang mengandung kadar amilopektin tinggi sehingga produknya mengembang. Tepung jagung memiliki kadar amilopektin tinggi (Cynthia et al. 2009) sehingga kemungkinan dapat diolah menjadi produk crackers atau opak.

\section{BAHAN DAN METODE}

\section{Bahan}

Bahan-bahan yang digunakan dalam penelitian ini meliputi jagung varietas BPPT-IPB 1 (masih dalam tahap sertifikasi), tepung ketan, garam, gula, baking powder, dan minyak sawit.

\section{Metode}

Pada penelitian tahap awal dilakukan pembuatan tepung jagung. Pembuatan tepung jagung dilakukan melalui tahapan pemipilan jagung, perendaman, penirisan, pembuangan perikarp dan tip cap, pengecilan ukuran, pembuangan lembaga dan sisa perikarp (pencucian), penirisan, pengeringan oven $60^{\circ} \mathrm{C}$, penepungan, pengeringan oven $60^{\circ} \mathrm{C}$, dan pengayakan (120 mesh). Analisis sifat fisik tepung jagung meliputi rendemen dan sifat amilografi. Analisis komposisi kimia tepung jagung meliputi proksimat (AOAC, 1995), kadar serat kasar (AOAC 1995), kadar pati (AOAC, 1995), dan kadar amilosa serta amilopektin (AOAC, 1995).

Pada penelitian utama dilakukan pembuatan crackers jagung dan pendugaan umur simpannya dengan menggunakan pendekatan kadar air kritis. Dalam pembuatan crackers jagung, dilakukan formulasi bahan dasar yaitu tepung jagung dan tepung ketan dengan perlakuan jumlah tepung jagung 50-100\% dari total tepung yang digunakan (Tabel 1). Bahan-bahan lain yang diperlukan dalam pembuatan crackers jagung adalah gula, garam, air, baking powder, dan minyak sawit. Formulasi crackers jagung didasarkan pada Putra (2005) yang telah dimodifikasi seperti tertera pada Tabel 2.

Tabel 1. Formulasi tepung untuk crackers jagung

\begin{tabular}{ccc}
\hline Formula & Tepung Jagung $(\%)$ & Tepung Ketan $(\%)$ \\
\hline F1 & 50 & 50 \\
F2 & 60 & 40 \\
F3 & 70 & 30 \\
F4 & 80 & 20 \\
F5 & 90 & 10 \\
F6 & 100 & 0 \\
\hline
\end{tabular}

Tabel 2. Formula crackers jagung

\begin{tabular}{cc}
\hline Komponen & Jumlah \\
\hline Tepung* & 50 gram \\
Gula & 0.7 gram \\
Garam & $1 \mathrm{gram}$ \\
Air & $43 \mathrm{~mL}$ \\
Baking powder & $0.7 \mathrm{gram}$ \\
Minyak sawit & $9 \mathrm{~mL}$ \\
\hline
\end{tabular}

Proses pembuatan crackers jagung melalui tahapan pencampuran bahan, gelatinisasi pertama, pembentukan lembaran, pencetakan, gelatinisasi kedua, pendinginan, dan pemanggang- an (Gambar 1). Produk crackers jagung yang dihasilkan diuji secara organoleptik (rating hedonik) untuk menentukan formula terbaik. Pengujian dilakukan menggunakan 30 orang panelis semi terlatih terhadap parameter kerenyahan dan overall. Skala hedonik yang digunakan adalah sangat tidak suka (skala $=1$ ) sampai sangat suka (skala $=5$ ). Untuk mengetahui pengaruh perlakuan terhadap tingkat kesukaan panelis, maka dilakukan analisis ragam (ANOVA) terhadap data hasil uji organoleptik. Jika berdasarkan hasil ANOVA dinyatakan terdapat perbedaan nyata, maka dilanjutkan dengan uji Duncan.

Produk crackers jagung terbaik kemudian diukur kerenyahan dan kekerasannya. Selain itu dilakukan pengukuran rasio pengembangan, analisis kimia (proksimat, kadar serat kasar, kadar pati, kadar amilosa dan amilopektin) dan pendugaan umur simpan terhadap produk crackers jagung terbaik.

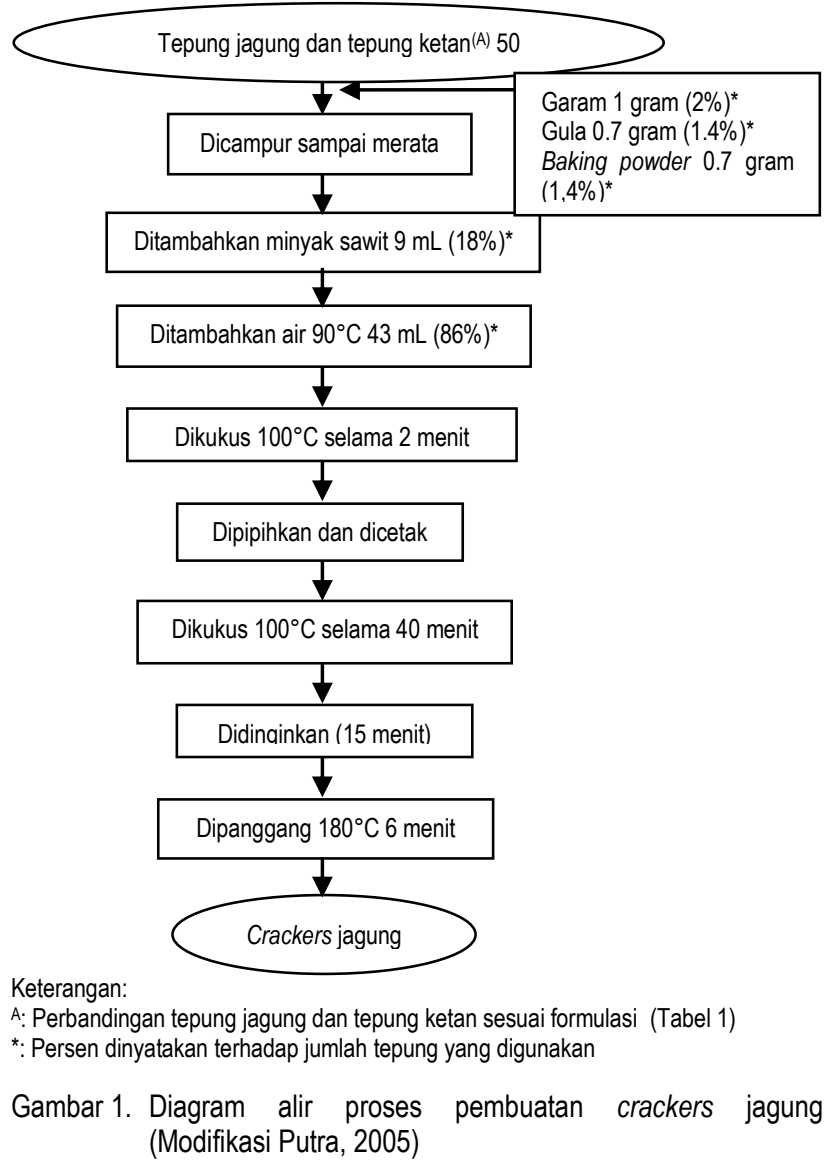

Pengukuran kerenyahan dan kekerasan crackers dilakukan dengan menggunakan texture analyzer XT-2i (Gambar 2) yang dinyatakan sebagai gaya tekan dalam satuan gf (gram force). Probe yang digunakan berbentuk bola (spherical stainless probe $P / 0.25 S$ ). Pengukuran dilakukan dengan kecepatan probe $1 \mathrm{~mm} /$ detik, jarak $5 \mathrm{~mm}$, dan gaya tekan (triger force) 100 g. Hasil pengukuran berupa grafik seperti pada Gambar 3.

Pendugaan umur simpan produk crackers jagung dilakukan dengan pendekatan kadar air kritis menggunakan kurva isotermis sorpsi air. Tahapan pendugaan umur simpan adalah penentuan atribut utama dan kerusakan produk, pembuatan kurva isotermis sorpsi air, penentuan kadar air kritis, penentuan model persamaan isotermis sorpsi air dan uji ketepatan model, 
serta perhitungan umur simpan produk menggunakan persamaan Labuza (1982).
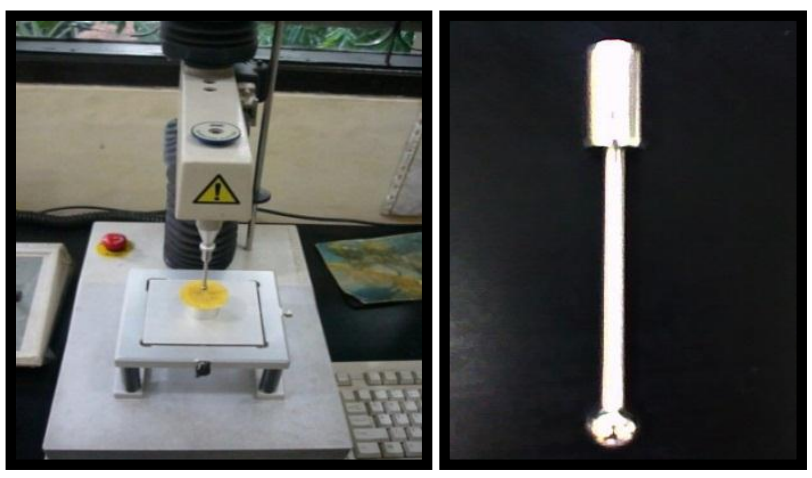

Gambar 2. Texture analyzer XT-2i (kiri) dan spherical probe (kanan)

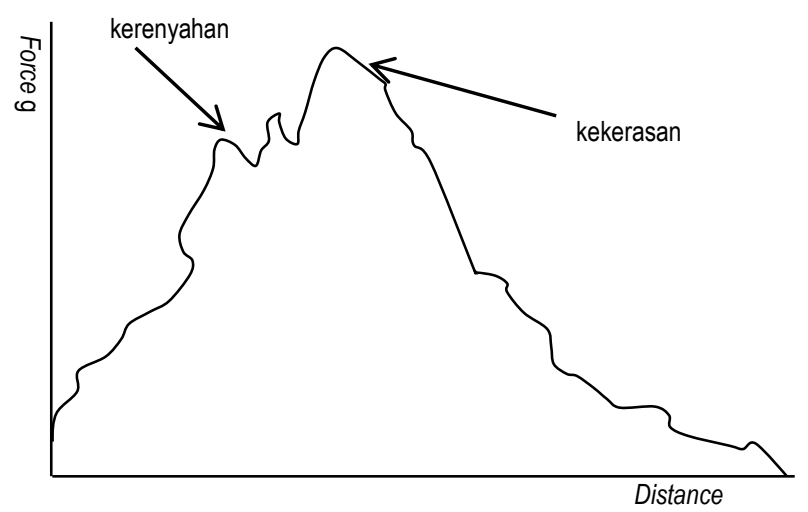

Gambar 3. Profil kerenyahan dan kekerasan hasil pengukuran texture analyzer XT-2i

Penentuan atribut utama dan kerusakan produk dilakukan melalui pengisian kuisioner oleh 30 panelis. Panelis diminta untuk mengurutkan empat atribut mutu yang telah ditentukan dengan menggunakan uji ranking. Keempat atribut mutu tersebut adalah warna, aroma, rasa, dan kerenyahan (tekstur). Atribut mutu yang memiliki nilai urutan paling kecil merupakan atribut utama. Selain itu, atribut utama kerusakan produk juga ditentukan melalui pengisian kuisioner. Panelis diminta memilih atribut yang paling penting dalam menentukan kerusakan produk.

Penentuan kurva isotermis sorpsi air diawali dengan pembuatan larutan garam jenuh dimana sejumlah garam ditimbang (Tabel 4) dan dimasukkan ke dalam desikator. Selanjutnya, ditambahkan sejumlah air (Tabel 4) sambil diaduk sehingga diperoleh larutan garam jenuh. Desikator kemudian ditutup dan dibiarkan selama 24 jam pada suhu $30^{\circ} \mathrm{C}$. Sampel sebanyak kurang lebih 1-2 gram diletakkan pada cawan aluminium kosong yang telah diketahui beratnya. Cawan yang berisi sampel tersebut lalu diletakkan dalam desikator yang berisi larutan garam jenuh. Desikator kemudian disimpan dalam ruang dengan suhu $30^{\circ} \mathrm{C}$. Sampel dalam cawan kemudian ditimbang bobotnya secara periodik setiap hari sampai diperoleh bobot konstan yang artinya kadar air kesetimbangan telah tercapai. Sampel yang telah mencapai bobot konstan lalu diukur kadar airnya dengan metode oven (AOAC, 1995) dan dinyatakan dalam basis kering. Hal ini dilakukan untuk memperoleh data kadar air kesetimbangan yang diplotkan dengan nilai aktivitas air (aw) sehingga dapat dibuat kurva isotermis sorpsi produk.

Tabel 4. Jenis garam dan air untuk preparasi larutan garam jenuh

\begin{tabular}{lccc}
\hline \multirow{2}{*}{ Jenis Garam } & $\begin{array}{c}\text { Kelembaban } \\
\text { Udara (\%) }\end{array}$ & \multicolumn{2}{c}{ Jumlah } \\
\cline { 3 - 4 } & 11 & 60 & Air $(\mathrm{mL})$ \\
\hline $\mathrm{LiCl}$ & 32 & 60 & 30 \\
$\mathrm{MgCl} 2$ & 69 & 60 & 8 \\
$\mathrm{KI}$ & 75 & 60 & 15 \\
$\mathrm{NaCl}$ & 84 & 60 & 25 \\
$\mathrm{KCl}$ & 90 & 60 & 25 \\
$\mathrm{BaCl}_{2}$ & & &
\end{tabular}

${ }^{*}$ Sumber: Spiess dan Wolf (1987)

Penentuan kadar air kritis diawali dengan menyimpan produk pada suhu ruang selama 5 hari. Setiap hari dilakukan pengambilan sampel dan dilakukan pengukuran kadar air, kerenyahan (menggunakan texture analyzer) serta uji hedonik terhadap tekstur (skala 1-7). Hasil uji hedonik dibandingkan dengan hasil pengukuran kadar air sehingga didapatkan kurva hubungan antara kadar air produk selama penyimpanan dengan skor hedonik. Produk yang telah ditolak oleh panelis secara organoleptik (skor 3) ditetapkan telah mencapai kadar air kritisnya.

Penentuan model persamaan kurva isotermis sorpsi dari kadar air kesetimbangan dilakukan untuk mendapatkan bentuk kecenderungan hubungan antara aw dan kadar air kesetimbangan yang lebih reliable. Dalam hal ini digunakan lima model persamaan yaitu persamaan Hasley, Chen-Clayton, Henderson, Caurie, dan Oswin. Model-model persamaan isotermis sorpsi air ini atau modifikasinya telah digunakan oleh banyak peneliti sebelumnya (Toğrul dan Arslan 2007; Ghodake et al. 2007; García-Pérez et al. 2008; Polatoğlu et al. 2011; Vishwakarma et al. 2011; Raji dan Ojediran, 2011). Model-model persamaan matematis yang digunakan dimodifikasi bentuknya dari persamaan non-linear menjadi persamaan linear untuk memudahkan perhitungan (Tabel 5).

Untuk menguji ketepatan model persamaan isotermis sorpsi digunakan Mean Relative Determination (MRD). Jika nilai MRD kurang dari 5, maka model isotermis sorpsi tersebut dapat menggambarkan keadaan yang sebenarnya atau sangat tepat. Jika nilai MRD antara 5 dan 10, maka model tersebut agak tepat menggambarkan keadaan yang sebenarnya. Jika nilai MRD lebih dari 10, maka model tersebut tidak tepat menggambarkan kondisi yang sebenarnya. Dari persamaan yang paling tepat, ditentukan nilai b (kemiringan kurva isotermis sorpsi yang diasumsikan linier antara Mi dan Mc) untuk dimasukkan dalam rumus umur simpan Labuza (1982). Rumus MRD adalah sebagai berikut:

$$
\operatorname{MRD}=\frac{100}{n} \sum_{i=1}^{n}\left|\frac{M i-M p i}{M i}\right|
$$

Dimana: $\mathrm{Mi}=$ kadar air percobaan Mpi = kadar air hasil perhitungan $\mathrm{n}=$ jumlah data 
Dalam perhitungan umur simpan, ditentukan nilai beberapa variabel untuk melengkapi persamaan umur simpan. Variabel tersebut adalah permeabilitas kemasan, berat kering produk per kemasan (Ws), luas kemasan $\left(\mathrm{m}^{2}\right)$, serta tekanan uap air jenuh. Umur simpan produk kemudian dihitung dengan menggunakan persamaan Labuza (1982):

$$
\mathrm{ts}=\frac{\ln \left(\frac{M e-M i}{M e-M c}\right)}{\frac{k}{x} \frac{A}{W s} \frac{P o}{b}}
$$

Dimana :

$$
\begin{aligned}
\mathrm{t}_{\mathrm{s}}= & \text { waktu kadaluwarsa (hari) } \\
\mathrm{Me}= & \text { kadar air keseimbangan produk }\left(\mathrm{g} \mathrm{H}_{2} \mathrm{O} / \mathrm{g} \mathrm{bk}\right) \\
\mathrm{Mi}= & \text { kadar air awal produk }\left(\mathrm{g} \mathrm{H}_{2} \mathrm{O} / \mathrm{g} \mathrm{bk}\right) \\
\mathrm{Mc}= & \text { kadar air kritis }\left(\mathrm{g} \mathrm{H}_{2} \mathrm{O} / \mathrm{g} \mathrm{bk}\right) \\
\mathrm{b}= & \text { kemiringan (slope) kurva isotermis sorpsi pada daerah antara Mi dan } \\
& \text { Mc } \\
\mathrm{k} / \mathrm{x}= & \text { konstanta permeabilitas uap air kemasan }\left(\mathrm{g} / \mathrm{m}^{2}\right. \text {.hari.mmHg) } \\
\mathrm{A}= & \text { luas permukaan kemasan }\left(\mathrm{m}^{2}\right) \\
\mathrm{Ws}= & \text { berat kering produk dalam kemasan }(\mathrm{g}) \\
\mathrm{Po}= & \text { tekanan uap air jenuh }(\mathrm{mmHg})
\end{aligned}
$$

\begin{tabular}{|c|c|c|}
\hline Model & Bentuk Linear & Nilai $y=a x+b$ \\
\hline Hasley & $\begin{array}{l}\log [\ln (1 / a w)]=\log P(1)- \\
P(2) \log M e\end{array}$ & $\begin{array}{l}y=\log [\ln (1 / a w)] \\
x=\log M e \\
a=\log P(1) \\
b=-P(2)\end{array}$ \\
\hline Chen-Clayton & $\begin{array}{l}\ln [\ln (1 / a w)]=\ln P(1)-P(2) \\
\mathrm{Me}\end{array}$ & $\begin{array}{l}y=\ln [\ln (1 / a w) \\
x=M e \\
a=\ln P(1) \\
b=-P(2)\end{array}$ \\
\hline Henderson & $\begin{array}{l}\log \left[\ln \left(1 /\left(1-a_{w}\right)\right]=\log K+n\right. \\
\log M e\end{array}$ & $\begin{array}{l}y=\log \left[\ln \left(1 /\left(1-a_{w}\right)\right]\right. \\
x=\log M e \\
a=\log \mathrm{K} \\
b=n\end{array}$ \\
\hline Caurie & $\ln M e=\ln P(1)-P(2) a_{w}$ & $\begin{array}{l}y=\ln M e \\
x=a_{w} \\
a=\ln P(1) \\
b=-P(2)\end{array}$ \\
\hline Oswin & $\begin{array}{l}\ln M e=\ln P(1)+P(2) \\
\ln [a w /(1-a w)]\end{array}$ & $\begin{array}{l}y=\ln M e \\
x=\ln [a w /(1-a w)] \\
a=\ln P(1) \\
b=P(2)\end{array}$ \\
\hline
\end{tabular}

Tabel 5. Bentuk linear model persamaan isotermis sorpsi (Rahayu et

\section{HASIL DAN PEMBAHASAN}

\section{Tepung jagung dan karakteristiknya}

Pembuatan tepung jagung 120 mesh melalui proses penggilingan kering menghasilkan rendemen sebesar $30.8 \%$ (dari berat jagung pipil). Rendemen yang kecil ini disebabkan karena sebagian fraksi grits jagung terlalu kering dan keras sehingga sulit dihancurkan. Disamping itu, adanya kehilangan selama proses juga mengakibatkan rendahnya rendemen tepung jagung yang diperoleh. Hasil penelitian lain yang menggunakan ayakan 100 mesh menghasilkan rendemen tepung jagung lebih tinggi yaitu 54.4\% (Fitriani, 2004) dan 50\% (Cynthia et al. 2009).

Hasil analisis amilografi menunjukkan bahwa tepung jagung memiliki suhu awal gelatinisasi $69^{\circ} \mathrm{C}$, viskositas maksimum 725 $\mathrm{BU}$, dan suhu puncak gelatinisasi $93.75^{\circ} \mathrm{C}$. Hasil analisis kimia menunjukkan bahwa tepung jagung memiliki kadar air $7.45 \%$.
Hal ini berarti kadar air tepung jagung memenuhi syarat mutu BSN, 1995 (SNI: 01-3727) yaitu maksimal 10\%. Kadar abu tepung jagung $0.13 \%$, sesuai SNI yaitu maksimal $1.5 \%$. Kadar protein tepung jagung $6.67 \%$ dan kadar lemaknya $2.38 \%$. Rendahnya kadar lemak pada tepung jagung disebabkan karena dilakukan proses pemisahan lembaga pada pembuatan tepung jagung, dimana terdapat kandungan lemak yang tinggi pada lembaga.

Kadar karbohidrat tepung jagung (by difference) 83.37\% dan kadar serat kasarnya $0.88 \%$. Kadar serat kasar pada tepung jagung masih sesuai dengan syarat mutu SNI yaitu maksimum 1.5\%. Kadar pati, amilosa, dan amilopektin tepung jagung berturut-turut $59.39,27.90$, dan $31.49 \%$.

\section{Skor kesukaan produk crackers jagung}

Produk crackers jagung yang dihasilkan diuji untuk menentukan produk terbaik. Dalam penentuan produk terbaik, dilakukan uji organoleptik terhadap atribut kerenyahan dan overall (penerimaan produk secara keseluruhan). Berdasarkan uji organoleptik, skor rata-rata kesukaan panelis terhadap kerenyahan crackers jagung berkisar antara 2.9-4.3 atau tidak suka hingga suka (Gambar 4).

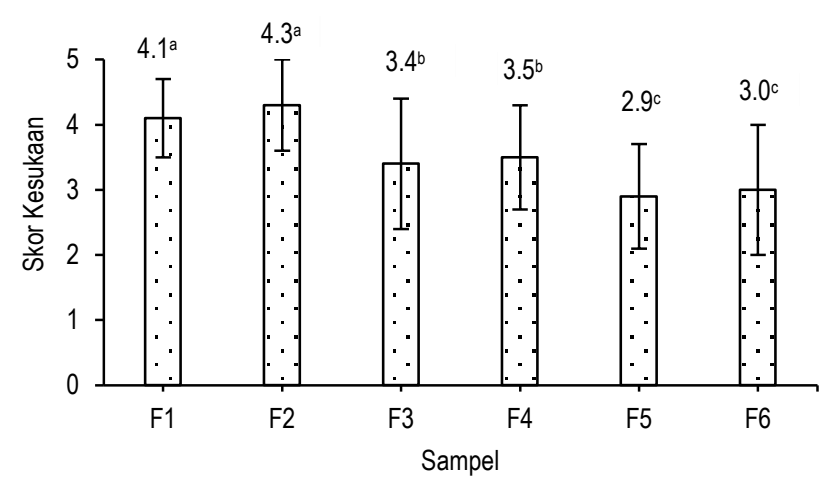

Keterangan: Angka-angka yang diikuti dengan huruf yang sama menunjukkan nilai yang tidak berbeda nyata $(p>0.05)$

$\mathrm{F} 1=$ tepung jagung : tepung ketan (50:50)

$\mathrm{F} 2=$ tepung jagung : tepung ketan $(60: 40)$

$\mathrm{F} 3=$ tepung jagung : tepung ketan $(70: 30)$

F4 = tepung jagung : tepung ketan (80:20)

$\mathrm{F} 5=$ tepung jagung : tepung ketan $(90: 10)$

F6 = tepung jagung : tepung ketan (100:0)

\section{Gambar 4. Skor rata-rata kesukaan terhadap kerenyahan}

Hasil ANOVA menunjukkan bahwa atribut kerenyahan mempunyai nilai signifikansi $0.000 \quad(p<0.05)$. Hal ini berarti bahwa perlakuan formulasi berpengaruh nyata terhadap skor kesukaan panelis terhadap kerenyahan sampel pada taraf nyata $5 \%$. Oleh karena itu, dilakukan uji lanjut Duncan yang menyatakan bahwa sampel F1 (50:50) dan F2 (60:40) tidak berbeda nyata, tetapi berbeda dengan sampel lainnya. Sampel F1 dan F2 paling disukai oleh panelis dibandingkan sampel lainnya.

Tingkat kesukaan panelis terhadap atribut overall berkisar antara 3.2-4.1 atau netral sampai suka (Gambar 5). Hasil ANOVA menunjukkan bahwa perbedaan formulasi tepung jagung dan ketan yang digunakan pada pembuatan crackers berpengaruh nyata pada skor kesukaan panelis terhadap atribut 
overall pada taraf nyata $5 \%$. Hasil uji lanjut Duncan menunjukkan bahwa sampel F1 dan F2 tidak berbeda nyata, tetapi berbeda dengan sampel lainnya. Sampel F1 dan F2 paling disukai oleh panelis.

Dari hasil pengujian organoleptik terhadap kerenyahan dan overall menunjukkan bahwa sampel F1 dan F2 paling disukai oleh panelis. Penentuan produk crackers jagung terbaik didasarkan pada formula yang memiliki basis tepung jagung terbanyak yaitu sampel F2 (60:40).

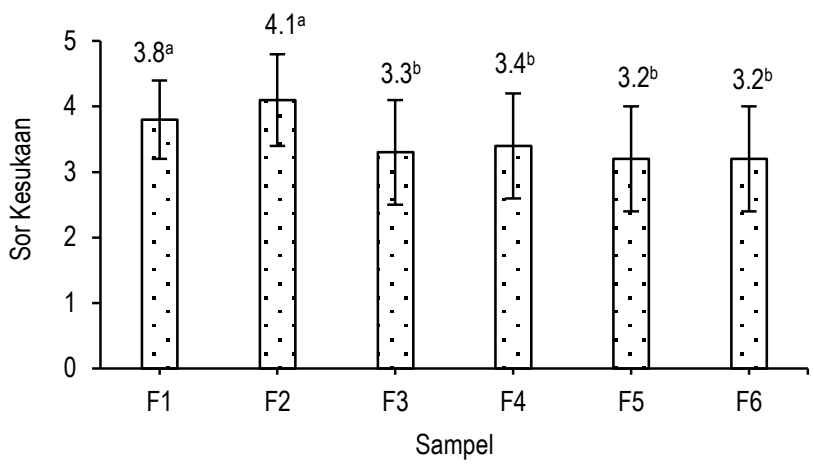

Keterangan: Angka-angka yang diikuti dengan huruf yang sama menunjukkan nilai yang tidak berbeda nyata $(p>0.05)$

$\mathrm{F} 1=$ tepung jagung : tepung ketan (50:50)

$\mathrm{F} 2=$ tepung jagung : tepung ketan $(60: 40)$

F3 = tepung jagung : tepung ketan (70:30)

$\mathrm{F} 4=$ tepung jagung : tepung ketan $(80: 20)$

$\mathrm{F} 5=$ tepung jagung : tepung ketan $(90: 10)$

F6 = tepung jagung : tepung ketan (100:0)

\section{Gambar 5. Skor rata-rata kesukaan terhadap overall}

Kerenyahan dan kekerasan produk crackers jagung terpilih

Produk crackers memiliki ciri utama berupa teksturnya yang renyah. Disamping kerenyahan, kekerasan menjadi atribut yang penting untuk produk crackers. Kekerasan suatu produk menunjukkan besarnya gaya yang dibutuhkan untuk membuat produk mengalami pecah. Prinsip ini digunakan dalam pengukuran kekerasan yaitu besarnya gaya tekan yang diperlukan untuk memecahkan produk.

Uji obyektif atribut kerenyahan dan kekerasan dilakukan pada produk crackers jagung dan rice crackers komersial sebagai pembanding. Nilai kerenyahan dan kekerasan crackers jagung dan rice crackers komersial dapat dilihat pada Tabel 6. Data pada tabel tersebut menunjukkan bahwa crackers jagung lebih mudah hancur akibat gaya tekan yang diberikan. Hal ini menandakan bahwa crackers jagung lebih renyah dan lebih lunak dibandingkan dengan rice crackers komersial. Kerenyahan dan kelunakan crackers jagung disebabkan karena salah satu bahan bakunya adalah tepung ketan yang mempunyai kandungan amilopektin tinggi. Amilopektin diketahui membuat produk bersifat renyah dan lunak.

Tabel 6. Nilai kerenyahan dan kekerasan crackers jagung dibandingkan rice crackers komersial

\begin{tabular}{lcc}
\hline \multicolumn{1}{c}{ Parameter } & Crackers Jagung & Rice Crackers Komersial \\
\hline Kerenyahan (gf) & $250.8 \pm 12.0$ & $385.7 \pm 87.7$ \\
Kekerasan (gf) & $384.7 \pm 40.6$ & $1850.5 \pm 192.9$ \\
\hline
\end{tabular}

\section{Rasio pengembangan produk crackers jagung terpilih}

Penentuan nilai rasio pengembangan produk dilakukan dengan membandingkan diameter dan ketebalan adonan crackers jagung sebelum dipanggang dengan diameter dan ketebalan produk setelah dipanggang. Berdasarkan data yang diperoleh, rata-rata nilai derajat pengembangan produk adalah $11 \%$. Nilai ini menunjukkan bahwa secara umum produk tidak terlalu mengembang. Hal ini disebabkan karena oven yang digunakan pada proses pemanggangan kurang memberikan panas secara cepat pada adonan.

\section{Komposisi kimia produk crackers jagung terpilih}

Produk crackers jagung mempunyai kadar air yang relatif rendah yaitu $4.67 \%$. Kadar air pada produk crackers merupakan karakteristik kritis yang memengaruhi penerimaan konsumen karena kadar air ini menentukan kerenyahan crackers. Kandungan air yang tinggi membuat crackers tidak renyah sehingga kurang disukai. Jika dibandingkan dengan syarat mutu biskuit dimana kadar airnya maksimal 5\% sesuai BSN, 1992 (SNI 01-2973), maka kadar air crackers jagung masih memenuhi syarat. Kadar air yang rendah memungkinkan aktivitas mikroba terhambat sehingga crackers memiliki umur simpan relatif lama.

Kadar protein, kadar lemak dan kadar abu produk crackers jagung masing-masing adalah 5.36, 7.46 dan 1.90\%. Hasil perhitungan (by difference) menunjukkan kadar karbohidrat crackers jagung adalah $80.61 \%$. Komponen karbohidrat yang banyak terdapat pada produk crackers jagung adalah pati. Crackers jagung mengandung kadar pati 58.98\%. Tingginya kadar pati pada crackers jagung disebabkan karena bahan baku utama berupa tepung jagung dan tepung ketan. Kadar amilosa dan kadar amilopektin crackers jagung masing-masing adalah 16.98 dan $42.00 \%$. Kadar serat kasar crackers jagung adalah $1.50 \%$.

\section{Atribut utama dan kerusakan}

Hasil uji statistik dengan Friedman Test menunjukkan bahwa atribut rasa dan kerenyahan merupakan atribut utama produk crackers jagung (memiliki skor ranking terendah). Nilai Asymp. Sig (0.000) lebih kecil dari taraf signifikansi yang digunakan (0.05) yang berarti atribut mutu produk berbeda nyata pada taraf 5\%. Uji LSD rank (Least Significant Difference) yang dilakukan sebagai uji lanjutan menunjukkan bahwa atribut rasa dan kerenyahan tidak berbeda pada taraf $5 \%$. Oleh karena itu, atribut kerenyahan dan rasa merupakan atribut utama produk crackers jagung. Hasil uji dapat dilihat pada Gambar 6 .

Penentuan atribut kerusakan produk dilakukan dengan meminta panelis untuk memilih salah satu atribut yang paling menentukan kerusakan mutu crackers secara umum sehingga produk tersebut ditolak oleh konsumen. Hasil kuisioner menunjukkan bahwa atribut tekstur merupakan penyebab kerusakan produk crackers. Sebanyak 27 panelis dari 30 panelis menyatakan bahwa atribut tekstur merupakan atribut kerusakan produk crackers jagung. 


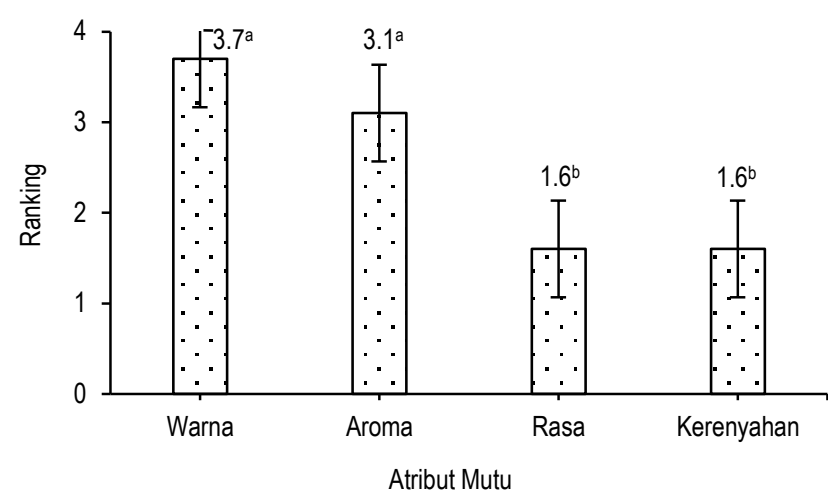

Gambar 6. Skor ranking atribut crackers jagung berdasarkan hasil kuisioner

\section{Kadar air kesetimbangan dan kurva isotermis sorpsi}

Hasil analisis kadar air kesetimbangan digunakan untuk membuat kurva isotermis sorpsi. Kurva isotermis sorpsi merupakan hubungan kadar air kesetimbangan dengan aw (Gambar 7). Kurva isotermis sorpsi produk crackers jagung berbentuk sigmoid seperti halnya bentuk kurva isotermis sorpsi bahan pangan pada umumnya (Spiess dan Wolf, 1987).

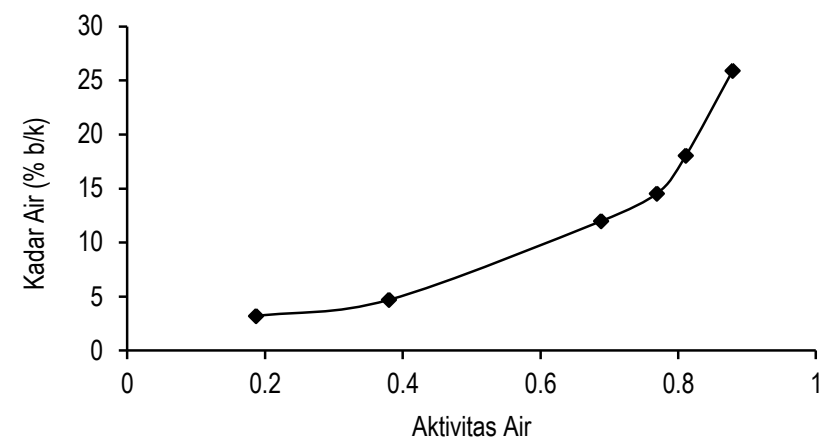

Gambar 7. Kurva isotermis sorpsi produk crackers jagung

\section{Kadar air kritis}

Kadar air sangat menentukan mutu produk kering (Mazumder et al. 2007; Rahman et al. 2009). Kadar air pada saat produk tidak dapat diterima mutunya disebut kadar air kritis. Kadar air kritis produk pangan umumnya dinyatakan dalam basis berat kering (bk) dan nilainya berbeda untuk masing-masing produk pangan. Pada penelitian ini, penentuan kadar air kritis dilakukan melalui uji hedonik dan uji rating tekstur terhadap produk crackers jagung.

Pada penentuan dengan uji hedonik, kadar air kritis crackers jagung ditentukan pada saat kerenyahan crackers tidak dapat diterima oleh panelis yaitu pada saat kesukaan panelis berada pada taraf agak tidak suka (skor 3). Penentuan kadar air kritis crackers jagung didasarkan pada bentuk linier kurva hubungan kadar air crackers jagung dengan skor kesukaan panelis seperti yang terlihat pada Gambar 8. Kadar air kritis crackers yang diperoleh melalui uji hedonik adalah $0.0990 \mathrm{~g} \mathrm{H}_{2} \mathrm{O} / \mathrm{g} \mathrm{bk}$.

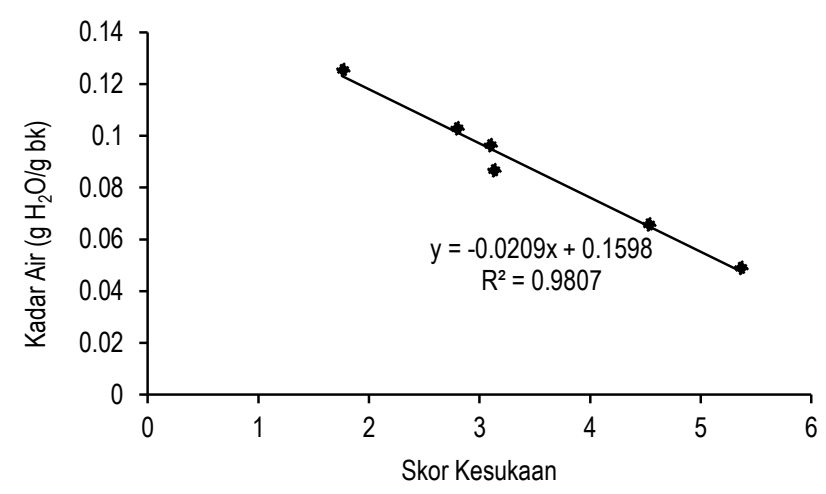

Gambar 8. Penentuan kadar air kritis crackers jagung melalui uji hedonik

Kadar air kritis crackers jagung juga dapat ditentukan pada saat kerenyahan crackers tidak dapat diterima oleh panelis. Kondisi tersebut ditetapkan pada saat skor rating 3 (agak tidak renyah). Penentuan kadar air kritis crackers jagung didasarkan pada bentuk linier kurva hubungan kadar air crackers jagung dengan skor rating kerenyahan seperti yang terlihat pada Gambar 9. Kadar air kritis crackers jagung yang diperoleh melalui uji rating tekstur adalah $0.0990 \mathrm{~g} \mathrm{H}_{2} \mathrm{O} / \mathrm{g}$ bk.

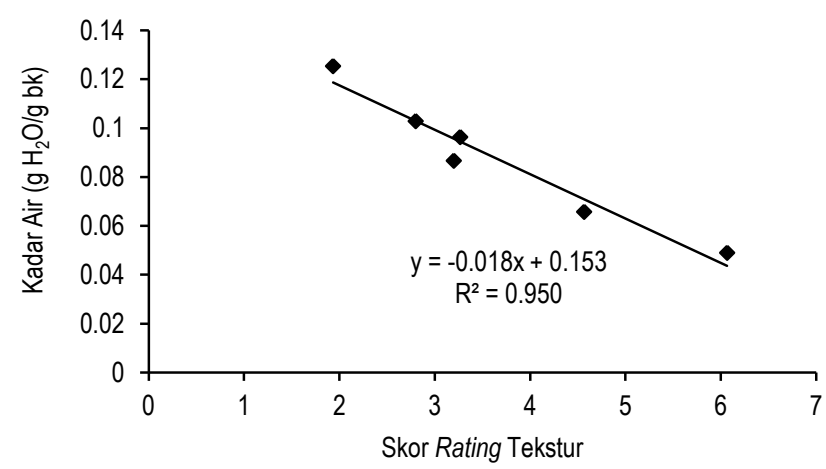

Gambar 9. Penentuan kadar air kritis crackers melalui uji rating tekstur

Kadar air kritis produk crackers jagung berdasarkan uji hedonik dan uji rating tekstur mempunyai nilai yang sama yaitu 9.9\% (bk). Beberapa penelitian sebelumnya telah melaporkan kadar air kritis produk pangan yang berbeda, antara lain tepung penyalut $16 \%$ bk (Sugiyono et al. 2010), biskuit adonan lunak $6.41 \%$ bk, biskuit adonan keras $6.88 \%$ bk (Kusnandar et al. 2010), beras ubi $11.68 \%$ bk (Widowati et al. 2010), tortilla $6.68 \%$ bk (Budijanto et al. 2010), mi kering ubi jalar 10.10\% bk (Sugiyono et al. 2011), dan bubuk putih telur ayam 12\% bk (Rao dan Labuza, 2012).

\section{Model isotermis sorpsi}

Model persamaan matematis yang digunakan adalah model Hasley, Chen-Clayton, Henderson, Caurie, dan Oswin. Modelmodel persamaan matematis yang digunakan dimodifikasi bentuknya dari persamaan non linear menjadi persamaan linear sehingga dapat ditentukan nilai-nilai tetapannya dengan menggunakan metode kuadrat terkecil untuk mempermudah perhitungan. Model persamaan kurva isotermis sorpsi produk crackers jagung dapat dilihat pada Tabel 7 . 
Tabel 7. Persamaan kurva isotermis sorpsi produk crackers jagung

\begin{tabular}{lc}
\hline \multicolumn{1}{c}{ Model } & Persamaan \\
\hline Hasley & $\log \left(\ln \left(1 / \mathrm{a}_{\mathrm{w}}\right)\right)=-1.572-1.195 \log \mathrm{Me}$ \\
Chen-Clayton & $\ln \left(\ln \left(1 / \mathrm{a}_{\mathrm{w}}\right)\right)=0.535-11.05 \mathrm{Me}$ \\
Henderson & $\log \left(\ln \left(1 /\left(1-\mathrm{a}_{\mathrm{w}}\right)\right)\right)=1.026+1.080 \log \mathrm{Me}$ \\
Caurie & $\ln \mathrm{Me}=-4.085+2.934 \mathrm{a}_{\mathrm{w}}$ \\
Oswin & $\ln \mathrm{Me}=-2.626+0.618 \ln \left(\mathrm{a}_{\mathrm{w}} /\left(1-\mathrm{a}_{\mathrm{w}}\right)\right.$ \\
\hline
\end{tabular}

Perbandingan kurva isotermis sorpsi hasil percobaan dengan model-model isotermis sorpsi yang dipilih memperlihatkan bahwa beberapa model isotermis sorpsi dapat menggambarkan keseluruhan kurva isotermis sorpsi hasil percobaan dengan tepat, agak tepat, dan kurang tepat. Semakin berhimpit antara kurva isotermis sorpsi percobaan dengan kurva isotermis model-model persamaan, maka kurva tersebut menggambarkan fenomena isotermis sorpsi semakin tepat (gambar tidak ditunjukkan). Hal ini diperkuat dengan hasil perhitungan nilai MRD (Mean Relative Determination) yang merupakan ukuran ketepatan antara kadar air kesetimbangan hasil perhitungan berdasarkan model dengan kadar air kesetimbangan hasil percobaan. Hasil perhitungan MRD pada Tabel 8 menunjukkan bahwa model Hasley adalah model yang paling tepat menggambarkan keseluruhan kurva isotermis sorpsi untuk produk crackers jagung hasil penelitian ini dengan nilai MRD terkecil yaitu 3.6980. Kurva isotermis sorpsi dari model persamaan Hasley yang dibandingkan dengan kurva isotermis sorpsi hasil per cobaan dapat dilihat pada Gambar 10.

Tabel 8. Hasil perhitungan nilai MRD model-model persamaan

\begin{tabular}{lc}
\hline \multicolumn{1}{c}{ Model Persamaan } & MRD \\
\hline Hasley & 3.6980 \\
Chen-Clayton & 25.0833 \\
Henderson & 11.7411 \\
Caurie & 8.2277 \\
Oswin & 5.8480 \\
\hline
\end{tabular}

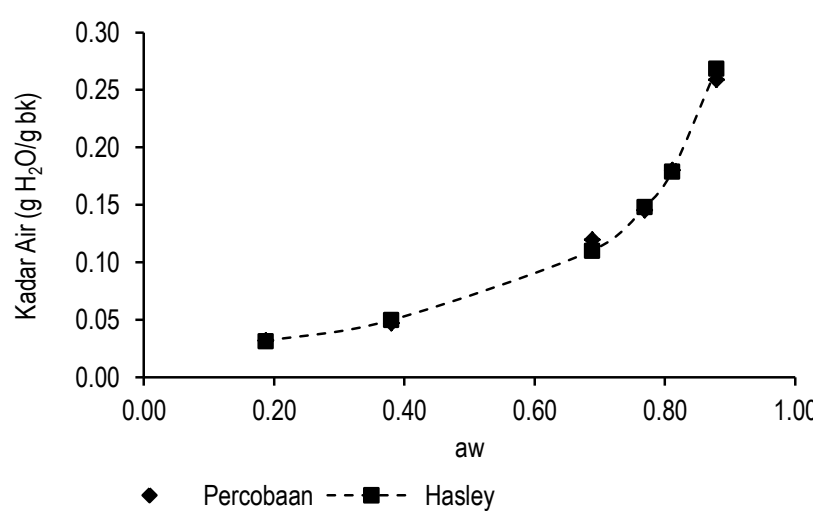

Gambar 10. Perbandingan kurva isotermis sorpsi hasil percobaan dengan model Hasley

Menurut Labuza (1982), daerah linier untuk menentukan nilai kemiringan (slope) kurva isotermis sorpsi diambil antara daerah kadar air awal (Mi) dan kadar air kritis (Mc). Oleh karena itu, penentuan nilai kemiringan (b) didasarkan pada kisaran $a_{w}$ 0.187-0.688 dengan menggunakan model persamaan yang tepat yaitu model Hasley. Hasil regresi linear pada kurva isotermis sorpsi menghasilkan persamaan garis $y=0.164 x-$ $0.004\left(R^{2}=0.97\right)$, dimana y adalah kadar air kesetimbangan ( $g$ $\mathrm{H}_{2} \mathrm{O} / \mathrm{g}$ bk) dan $\mathrm{x}$ adalah nilai $\mathrm{a}_{\mathrm{w}}$. Dari hasil regresi linier kurva isotermis sorpsi model Hasley, diperoleh nilai b (nilai kemiringan kurva/slope) sebesar 0.164 . Kurva penentuan nilai $b$ dapat dilihat pada Gambar 11.

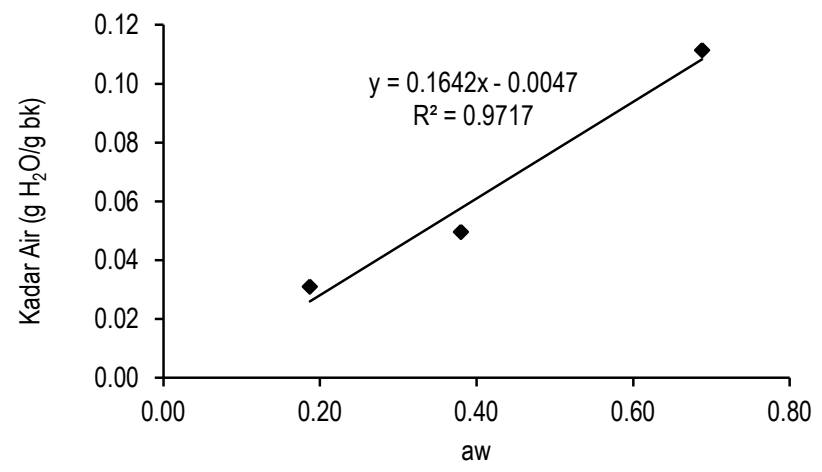

Gambar 11. Penentuan nilai kemiringan (slope) kurva isotermis sorpsi model Hasley

\section{Perhitungan umur simpan crackers jagung}

Perhitungan umur simpan produk didasarkan pada pergerakan kadar air produk mencapai kadar air kritis. Pergerakan kadar air produk mencapai kadar air kritis mengikuti kurva isotermis sorpsi. Oleh karena itu, perhitungan umur simpan produk yang didasarkan pada kadar air kritis umumnya menggunakan kurva isotermis sorpsi seperti yang dilakukan oleh Debnath et al. (2002), Risbo (2003), Hayati et al. (2004), Siripatrawan dan Jantawat (2008), Roca et al. (2008), Sianipar et al. (2008), Sugiyono et al. (2010), Kusnandar et al. (2010), Widowati et al. (2010), Budijanto et al. (2010), Kulchan et al. (2010), Sugiyono et al. (2011), Escobedo-Avellaneda et al. (2012), Rao dan Labuza (2012), serta Jena dan Das (2012).

Pada perhitungan umur simpan produk, diperlukan data tambahan berupa berat kering produk per kemasan, permeabilitas kemasan, ukuran kemasan, dan tekanan uap air jenuh. Berat kering produk per kemasan merupakan berat awal crackers yang telah dikoreksi dengan kadar air awal (4.90\% $\mathrm{b} / \mathrm{k}$ ). Berat kering per kemasan (Ws) crackers adalah 45.70 gram. Kemasan yang digunakan untuk menyimpan crackers adalah metallized plastic. Data permeabilitas kemasan merupakan data sekunder, dimana nilai permeabilitas kemasan metallized plastic yang digunakan adalah 0.0136 $\mathrm{g} / \mathrm{m}^{2}$.hari.mmHg (Fitria, 2007). Kemasan yang digunakan mempunyai ukuran $18 \times 11 \times 2 \mathrm{~cm}^{2}$ atau sebesar $0.0396 \mathrm{~m}^{2}$. Tekanan uap air jenuh pada suhu penyimpanan $30^{\circ} \mathrm{C}$ adalah sebesar $31.8240 \mathrm{mmHg}$. Umur simpan crackers jagung ditentukan pada kondisi kelembaban udara 75 dan $85 \%$. Kadar air kritis produk crackers jagung adalah $0.0990 \mathrm{~g} \mathrm{H}_{2} \mathrm{O} / \mathrm{g} \mathrm{bk}$. Berdasarkan hasil perhitungan, umur simpan produk crackers jagung yang disimpan pada suhu $30^{\circ} \mathrm{C}$ menggunakan kemasan metallized plastic pada kelembaban udara $75 \%$ adalah 366 hari. Jika produk crackers jagung disimpan pada kelembaban udara $85 \%$, umur simpan produk menjadi 150 hari.

Beberapa penelitian telah melaporkan hasil perhitungan umur simpan produk pangan dengan menggunakan metode 
isotermis sorpsi. Umur simpan produk campuran bumbu kering 423 hari (Sianipar et al. 2008), tepung penyalut 209 hari (Sugiyono et al. 2010), biskuit adonan lunak 296 hari, biskuit adonan keras 306 hari (Kusnandar et al. 2010), beras ubi 127 hari (Widowati et al. 2010), tortilla 56 hari (Budijanto et al. 2010), mi kering ubi jalar 209 hari (Sugiyono et al. 2011), irisan bawang merah 86 hari dan irisan buncis 73 hari (EscobedoAvellaneda et al. 2012).

\section{KESIMPULAN}

Penelitian ini telah menunjukkan bahwa produk crackers dapat dibuat dari campuran tepung jagung dan tepung ketan. Produk terbaik dihasilkan dari campuran tepung jagung $60 \%$ dan tepung ketan $40 \%$. Produk crackers jagung mempunya rasio pengembangan $11 \%$, nilai kerenyahan 250.8 gf, serta nilai kekerasan 384.7 gf. Produk crackers jagung yang dihasilkan mempunyai kerenyahan dan kekerasan yang lebih baik dibandingkan dengan rice crackers komersial. Kurva isotermis sorpsi crackers jagung dapat digambarkan dengan tepat menggunakan model Hasley. Dengan menggunakan pendekatan kadar air kritis, produk crackers jagung yang dikemas dengan metallized plastic dan disimpan pada kelembaban udara $75 \%$ mempunyai umur simpan 366 hari. Jika produk crackers jagung disimpan pada kelembaban udara $85 \%$, maka umur simpan produk menjadi 150 hari.

\section{UCAPAN TERIMA KASIH}

Penelitian ini dibiayai oleh Badan Pengkajian dan Penerapan Teknologi (BPPT).

\section{DAFTAR PUSTAKA}

Agustina F. 2008. Kajian Formulasi dan Isotermisk Sorpsi Air Bubur Jagung Instan. [Tesis]. Bogor: Sekolah Pascasarjana, Institut Pertanian Bogor.

[AOAC] Association of Official Analitycal Chemists. 1995. Official Methods of Analysis of Association of Official Analytical Chemists. Association of Official Analitycal Chemists. Washington DC.

[BSN] Badan Standardisasi Nasional. 1992. SNI No. 01-29731992. Syarat Mutu Biskuit. Jakarta: Badan Standardisasi Nasional.

[BSN] Badan Standardisasi Nasional. 1995. SNI No. 01-37271995. Syarat Mutu Tepung Jagung. Jakarta: Badan Standardisasi Nasional.

[BPS] Badan Pusat Statistik. 2011. Tabel luas panenproduktivitas-produksi tanaman jagung seluruh provinsi. http://www.bps.go.id/tnmn_pgn.php?adodb_next_page=3\&e ng=0\&pgn=2\&prov=99\&thn1=2009\&thn2=2012\&luas=1\&pro duktivitas=1\&produksi=1. [15 Mei 2012].

Budijanto S, Sitanggang AB, Kartika YD. 2010. Penentuan umur simpan tortilla dengan metode akselerasi berdasarkan kadar air kritis serta pemodelan ketepatan isotherminya. J Teknol dan Industri Pangan 21: 165-170.

Cynthia G, Sugiyono, Haryanto B. 2009. Kajian formulasi biskuit jagung dalam rangka substitusi tepung terigu. J Teknol dan Industri Pangan 20: 32-40.

Debnath S, Hemavathy J, Bhat KK. 2002. Moisture sorption studies on onion powder. Food Chem 78: 479-482. DOI: 10.1016/S0308-8146(02)00161-9.

Departemen Perindustrian. 2007. Kebijakan Nasional Program Pengembangan Industri Pengolahan Berbasis Jagung. Jakarta: Direktorat Jenderal Industri Agro dan Kimia.

Escobedo-Avellaneda Z, Velazquez G, Torres JA, Welti-Chanes J. 2012. Inclusion of the variability of model parameters on shelf-life estimations for low and intermediate moisture vegetables. LWT-Food Sci Technol 47: 364-370. DOI: 10.1016/j.Iwt.2012.01.032.

Fitria M. 2007. Pendugaan Umur Simpan Produk Biskuit dengan Metode Akselerasi Berdasarkan Pendekatan Kadar Air Kritis. [Skripsi]. Bogor: Fakultas Teknologi Pertanian, Institut Pertanian Bogor.

Fitriani D. 2004. Kajian pengembangan Produk, Mikrostruktur dan Analisis Daya Simpan Mie Jagung Instant. [Tesis]. Bogor: Sekolah Pascasarjana, Institut Pertanian Bogor.

García-Pérez JV, Cárcel JA, Clemente G, Mulet A. 2008. Water sorption isotherms for lemon peel at different temperatures and isosteric heats. LWT-Food Sci Technol 41: 18-25. DOI: 10.1016/j.lwt.2007.02.010.

Ghodake HM, Goswami TK, Chakraverty A. 2007. Moisture sorption isotherms, heat of sorption and vaporization of withered leaves, black and green tea. J Food Eng 78: 827835. DOI: 10.1016/j.jfoodeng.2005.11.023.

Hayati R, Abdullah A, Ayob MK, Soekarto ST. 2004. Isotermis sorpsi air dan analisis umur simpan tongkol (Euthynnus affinis) kering dari Aceh. J Teknol dan Industri Pangan 15: 207-213.

Jena S, Das H. 2012. Shelf life prediction of aluminum foil laminated polyethylene packed vacuum dried coconut milk powder. J Food Eng 108: 135-142. DOI: 10.1016/j. jfoodeng.2011.06.036.

Kulchan R, Boonsupthip W, Suppakul P. 2010. Shelflife prediction of packaged cassava-flour-based baked product by using empirical models and activation energy for water vapor permeability of polyolefin films. J Food Eng 100: 461467. DOI: 10.1016/j.jfoodeng.2010.04.031.

Kusnandar F, Adawiyah DR, Fitria M. 2010. Pendugaan umur simpan produk biskuit dengan metode akselerasi berdasarkan pendekatan kadar air kritis. J Teknol dan Industri Pangan 21: 117-122.

Labuza TP. 1982. Shelf Life Dating of Foods. Food and Nutrition Press Inc., Westport, Connecticut.

Mazumder P, Roopa BS, Bhattacharya S. 2007. Textural attributes of a model snack food at different moisture contents. J Food Eng 79: 511-516. DOI: 10.1016/j.jfoodeng. 2006.02.011. 
Polatoğlu B, Beşe AV, Kaya M, Aktaş N. 2011. Moisture adsorption isotherms and thermodynamics properties of sucuk (Turkish dry-fermented sausage). Food Bioprod Process 89: 449-456. DOI: 10.1016/j.fbp.2010.06.003.

Putra GA. 2005. Pengaruh Cara Pengeringan dan Cara Pemanggangan terhadap Mutu Produk Opak Tepung Ketan Komersial (glutinous rice crackers). [Skripsi]. Bogor: Fakultas Teknologi Pertanian, Institut Pertanian Bogor.

Rahayu WP, Arpah M, Erika D. 2005. Penentuan waktu kadaluwarsa dan model sorpsi isotermis biji dan bubuk lada hitam (Piper ningrum L.). J Teknol dan Industri Pangan 16: 31-37.

Rahman MS, Al-Belushi RM, Guizani N, Al-Saidi GS, Soussi B. 2009. Fat oxidation in freeze-dried grouper during storage at different temperatures and moisture contents. Food Chem 114: 1257-1264. DOI: 10.1016/j.foodchem.2008.11.002.

Raji AO, Ojediran JO. 2011. Moisture sorption isotherms of two varieties of millet. Food Bioprod Process 89: 178-184. DOI: 10.1016/j.fbp.2010.06.001.

Rao Q, Labuza TP. 2012. Effect of moisture content on selected physicochemical properties of two commercial hen egg white powders. Food Chem 132: 373-384. DOI: 10.1016/j. foodchem.2011.10.107.

Risbo J. 2003. The dynamics of moisture migration in packaged multi-component food systems I: shelf life predictions for a cereal-raisin system. J Food Eng 58: 239-246. DOI: 10.1016/S0260-8774(02)00373-4.

Roca E, Broyart B, Guillard V, Guilbert S, Gontard N. 2008. Predicting moisture transfer and shelf-life of multidomain food products. J Food Eng 86: 74-83. DOI: 10.1016/j. jfoodeng.2007.09.012.

Sianipar D, Sugiyono, Syarief R. 2008. Kajian formulasi bumbu instan binthe biluhuta, karakteristik hidratasi dan pendugaan umur simpannya dengan menggunakan metode pendekatan kadar air kritis. J Teknol dan Industri Pangan 19: 32-39.
Siripatrawan U, Jantawat P. 2008. A novel method for shelflife prediction of a packaged moisture sensitive snack using multilayer perceptron neural network. Expert Syst Appl 34: 1562-1567. DOI: 10.1016/j.eswa.2007.01.008.

Spiess WEL, Wolf W. 1987. Critical Evaluation of Methods to Determine Moisture Sorption Isotherm. Di dalam Water Activity: Theory and Application to Food. Marcell Dekker Inc., New York.

Sugiyono, Setiawan E, Syamsir E, Sumekar H. 2011. Pengembangan produk mi kering dari tepung ubi jalar (Ipomomea batatas) dan penentuan umur simpannya dengan metode isoterm sorpsi. J Teknol dan Industri Pangan 22: 164-170.

Sugiyono, Fransisca, Yulianto A. 2010. Formulasi tepung penyalut berbasis tepung jagung dan penentuan umur simpannya dengan pendekatan kadar air kritis. J Teknol dan Industri Pangan 21: 95-101.

Sugiyono, Soekarto ST, Hariyadi P, Supriadi A. 2004. Kajian optimasi teknologi pengolahan beras jagung instan. J Teknol dan Industri Pangan 15: 119-128.

Supriadi A, Sugiyono, Soekarto ST, Hariyadi P. 2004. Kajian isotermis sorpsi air dan umur simpan beras jagung instan. Forum Pascasarjana 27: 221-230.

Toğrul H, Arslan N. 2007. Moisture sorption isotherms and thermodynamic properties of walnut kernels. J Stored Prod Res 43: 252-264. DOI: 10.1016/j.jspr.2006.06.006.

Vishwakarma RK, Shivhare US, Nanda SK. 2011. Moisture adsorption isotherms of guar (Cyamposis tetragonoloba) grain and guar gum splits. LWT-Food Sci Technol 44: 969975. DOI: 10.1016/j.Iwt.2010.09.002.

Widowati S, Herawati H, Syarief R, Suyatma NE, Prasetia HA. 2010. Pengaruh isoterm sorpsi air terhadap stabilitas beras ubi. J Teknol dan Industri Pangan 21: 123-128. 